\title{
Co-opetition models for governing professional football
}

\author{
Alessandra Lardo ${ }^{1 *}$, Raffaele Trequattrini ${ }^{1}$, Rosa Lombardi ${ }^{2}$ and Giuseppe Russo ${ }^{1}$
}

\author{
* Correspondence: \\ a.lardo@unicas.it \\ ${ }^{1}$ Department of Economics and \\ Law, University of Cassino and \\ Southern Lazio, Loc. Folcara, 03043 \\ Cassino, Italy \\ Full list of author information is \\ available at the end of the article
}

\begin{abstract}
In recent years, models for co-creating value in a business-to-business context have often been examined with the aim of studying the strategies implemented by and among organisations for competitive and co-operative purposes. The traditional concepts of competition and co-operation between businesses have now evolved, both in terms of the sector in which the businesses operate and in terms of the type of goods they produce.

Many researchers have, in recent times, investigated the determinants that can influence the way in which the model of co-opetition can be applied to the football world. Research interest lies in the particular features of what makes a good football. In this paper, the aim is to conduct an analysis of the rules governing the "football system", while also looking at the determinants of the demand function within football entertainment. This entails applying to football match management the co-opetition model, a recognised model that combines competition and co-operation with the view of creating and distributing value. It can, therefore, be said that, for a spectator, watching sport is an experience of high suspense, and this suspense, in turn, depends upon the degree of uncertainty in the outcome. It follows that the rules ensuring that both these elements can be satisfied are a fertile ground for co-operation between clubs, as it is in the interest of all stakeholders to offer increasingly more attractive football, in comparison with other competing products. Our end purpose is to understand how co-opetition can be achieved within professional football.
\end{abstract}

\section{Background Introduction}

In the post-industrial, knowledge-based economy of today's more developed nations, companies vary in their perspective of what constitutes value for business (Chase 1997; Del Giudice and Maggioni 2014).

Over recent years, models for co-creating value in a business-to-business context have often been examined with the purpose of studying the strategies implemented by and among organisations for competitive and co-operative purposes.

The traditional concepts of competition and co-operation between businesses have now evolved, both in terms of the sector in which the businesses operate and in terms of the type of goods they produce.

With the introduction of the concept of co-opetition (Cherington 1976; Brandenburger and Nalebuff 1996), scholars have tried to identify a theory that can go beyond the simple

(C) 2016 Lardo et al. Open Access This article is distributed under the terms of the Creative Commons Attribution 4.0 International License (http://creativecommons.org/licenses/by/4.0/), which permits unrestricted use, distribution, and reproduction in any medium, provided you give appropriate credit to the original author(s) and the source, provide a link to the Creative Commons license, and indicate if changes were made. 
conventional approach at the basis of the working relationship between companies operating in the same sector.

The term co-opetition is used to explain the simultaneous relationships that foment co-operation and competition between companies and which are the result of the complexity of the interests and objectives involved.

Over the years, this topic has been investigated from a number of perspectives. Several scholars have analysed how the co-opetition model has been applied in different industries and why it is used as a business strategy (Stein 2010; Kylänen and Rusko 2011).

According to our research, however, very few studies look at how the co-opetition model can be applied to the field of professional sport.

Up to now, research on professional sport has focused mainly on the various coopetition strategies and associated benefits (Stewart et al. 2005; Robert et al. 2009; Lorgnier and Su 2014). However, very few studies examine the methods used to implement these strategies or the workings of the co-opetition model.

Accordingly, the objective of this paper is to study how the sector of professional football operates, analysing its governance from a co-opetition perspective in order to identify the tools used for implementing this model.

Interest in this research came about because of the particular features of football and, specifically, to its experiential properties and the importance, from the point of view of enjoyment, of its subjective dimension in the form of relationships and its objective dimension in the form of uncertainty in match results. The ingredients necessary to keep competition alive in the sector of professional football are, in fact, the passionate involvement of football supporters and the uncertainty of the outcome. It is clear, therefore, that these elements depend on pride in the competition and unceasing rivalry between the teams competing in a tournament.

In the light of the above, in order to plug the previously identified gap in literature, the research question of this paper is the following:

$\mathrm{RQ}_{1}$ : What tools can be used to apply co-opetition to professional football?

In order to answer the research question, the paper is structured in the following way. After the introduction, the "Background" section includes also the literature review with particular reference to the role of co-opetition in professional sport. The second section contains the description of the methodology, considering the theoretical framework of reference and the context in which the research was carried out. The process in which co-opetition is applied to professional football is described in the third section. In the fourth, the discussion is presented, together with the implications deriving from the research. The fifth section contains the conclusions, the limitations of the study and the possible directions of future research.

\section{Literature review}

The concept of co-opetition was introduced for the first time in literature by Cherington (1976). However, it was only in 1996 that Brandenburger and Nalebuff brought the topic into public discussion and research with their book Co-opetition (Brandenburger and Nalebuff 1996).

According to Brandenburger and Nalebuff (1996), co-opetition is a revolutionary philosophy that combines competition and co-operation with the view of creating 
value. Value is generated through a co-operative process, capturing part of the value created through the competitive process.

In traditionally used competitive models, the general rule is to maximise profit and the way it is distributed. In co-operative models, all the players in a given sector constitute a systemic network for generating value. Each player acts as the complementor of the others, in the sense that all the business relationships between the players are based on complementarity.

Among other things, a co-opetition relationship can be founded on shared rules. According to Brandenburger and Nalebuff (1996), these rules can be either formal or informal. Formal rules are official and governmental, while informal rules are cultural in origin or are the effects of an agreement between the parties involved. Governmental and cultural rules are called "metarules" by the authors, since they are fixed from the outside, although lawmaking can be influenced through lobbying the various bodies involved.

Generally, it is thought that, through co-opetition, companies can increase their powers of innovation (Quintana-García and Benavides-Velasco 2004; Cherubini and Pattuglia, 2009; Soto-Acosta et al. 2015) and, as a consequence, their performance, especially through the trust-based relationships established among the network members (Carayannis and Campbell 2006; Dagnino and Rocco 2009; Trequattrini et al. 2012; Campanella et al. 2013).

Over the years, the concept of co-opetition has been examined from many angles (Stein 2010). One thread concerns the studies that look in detail at the theoretical basis of the relationships established between the many interested players. Another thread consists in the works where scholars have tried to present concrete evidence of coopetition by analysing cases involving a number of sectors.

Dagnino and Padula (2002) stated that there is the presumption of inter-dependence among the members of a network having the purpose of implementing co-opetition strategies, as this is a source for creating and distributing value. Inter-dependence can be at the basis of benefits for the partners, which are mutual but not necessarily equal because of the various kinds of pressure that can compromise this co-operation. It is also the basis for convergence of interests among several companies.

Zineldin (2004) has pointed out that the fundamental conditions for building a relationship founded on co-opetition are similar to a wedding. All participants must know each other, take part in the ceremony and sign the contract tying them together. Potential conflicts must be mended through transparent and shared agreements. All participants must be fully aware that divorce is always possible.

Luo (2004) defined co-opetition as a system in which all agents retain a certain level of inter-dependence without losing their organisational autonomy, and has applied it to international companies, starting from the assumption that increased competitive pressure is at the basis of the need for greater co-operation among multinationals. He has investigated co-opetition among global rivals, co-opetition among foreign governments and co-opetition within one multinational enterprise.

Gnywali et al. (2006) studied the relationship between the advantages and disadvantages of co-opetition in the context of how a company is positioned within a network. According to the author, the most closely linked companies are those most capable of influencing the network, while still retaining a high degree of autonomy.

In their analysis, Bakshi and Kleindorfer (2009) established the superiority of coopetition over competition in relation to managing supply chain security because co- 
operative contracts lead to investments being made in terms of security, in contrast with non-co-operative agreements.

A number of studies have been concerned with case-based papers at country, industry and company levels, which deal with critical issues relating to the management of co-opetition in different world arenas (Stein 2010; Kylänen and Rusko 2011).

Bojar and Drelichowski (2008) investigated the development of companies operating in the agricultural industry in many EU member countries. Despite the fact that agricultural companies are competitors, they have a number of common interests, such as building up the necessary infrastructure for large-scale production, the general development of rural areas and, linked to this, obtaining EU financial support. One feature of the co-opetition approach is that it helps to increase the power of the members' combined market compared to that of their competitors not taking part and in terms of their dealings with their customers.

Thematically, this paper is close to that of Song (2003), in which he explains that the importance of co-opetition in the port and docks industry is due to the efforts made over the preceding decade to introduce rationalising measures. Many port operators who previously had only managed their local operation have then extended their business to a regional or global scale.

Eriksson (2008), on analysing the Swedish construction industry, recognised that, because of the lack of confidence in co-operative action among contract partners, there is difficulty in applying co-opetition models. He argued that mistrust prevents co-operation for taking place according to the expectations set out in transaction cost theory. His aim was to demonstrate that companies can make unbiased and systematic procurement decisions (Lombardi et al. 2014a).

Considering the information technology industry, Gueguen (2009) studied cooperative behaviour among companies, showing the importance of setting technological standards and, therefore, the need for competitors to co-operate (Del Giudice et al. 2012; Palacios-Marqués et al. 2015).

In the sports sector, several studies have highlighted that league member clubs, in the course of a season, can simultaneously implement strategies of collaboration and of competition.

Robert et al. (2009) stated that football clubs gain financial benefits from the collective negotiation of some resources and suggest that there are three types of professional football clubs. These are the efficient (they rarely buy or sell players and use co-opetition strategies sparingly), the merchandisers (they strongly benefit from merchandising) and the co-opetitors (they earn great sums and have access to top players) (Lombardi et al. 2014b). This study also emphasises the role that football leagues have in optimising primary management resources, such as, for example, television rights.

Vernhet et al. (2011) have pointed out that strategies of co-opetition can be implemented through the mediation of leagues, which act as club intermediaries.

Although, in literature, adequate prominence has been given to the role of the governance bodies within the "football system", in very few studies has it been underlined that these bodies can act as tools used by clubs to develop co-opetition mechanisms, under the initial assumption that clubs take part, directly or indirectly, in elaborating the set of rules concerning the management of professional football. 
In this paper, the objective is to fill this gap in literature, drawing attention to the coopetition logics at the basis of rules introduced to regulate the game and those that govern the clubs' administrative side.

\section{Methods}

\section{Framework}

The study was carried out using an in-depth qualitative approach, consistent with our exploratory and descriptive aim (Glaser and Strauss 1967; Huberman and Miles 2002; Eisenhardt 1989).

This article is based on the theoretical framework proposed by Neale (1964), according to whom, the professional sports offer is, in fact, a combined product, in the sense that it is realised through the contribution of several parties. In this prospective, the stronger the competitor, the greater the gain of each participant in the competition, with this gain being strictly linked to the interest that the competition can excite in the spectators.

This idea can lead to the conclusion that sport is a sector in which the traditional principles of economy do not hold true, having considered that, for each individual player, achieving a position of absolute prominence is less advantageous than that potentially possible in a situation of perfect competition.

In order to place sport within the precepts of traditional economy, Neale distinguishes between economic and sporting competition. While clubs compete individually in a sports competition, this does not take place within an economic framework in which no one team can satisfy the overall market demand on its own. If this were the case, there would be no competitors for teams to match themselves against and the game would have no meaning.

The research uses secondary sources (Yin 2003) and includes documents, reports, news items, journal articles in open sources, papers, scientific books and databases.

\section{Context of the research}

This article is based on a study of the football sector, starting from the hypothesis that the objective of professional football club managers is to entertain the spectators, while trying, where possible, to win the games they play.

The ingredients necessary for keeping the competition alive are interest, uncertainty and passionate engagement in chasing results. On close examination, these elements demand pride in the competition and incessant rivalry between the teams taking part in the tournaments.

It is clear that, if the rivals are not good enough, there is no uncertainty or engagement in the result and this, in turn, means that supporters do not feel the need to identify themselves with their clubs or to proclaim their sense of belonging to them. A predictable championship where the same team always wins would lose its main attractiveness and reduce, at least on a temporary basis, spectator interest, which is a major source of economic value for sports entertainment.

These are considerations that clearly show the great difference between sports competition and competition in any economic sector. In sport, the aim is not to eliminate the weakest rival, since no team can do without the others and, in general, there is the feeling that a certain balance is essential to the competition. 
The idea of a type of competition where company strategy is such that competitive and co-operative behaviour can co-exist has already been expressed theoretically and is embedded in the concept of co-opetition.

Professional football is a typical sector in which the co-opetition model dominates. Winning the European Champions League does not merely benefit the winning club, but all the clubs in the same national league, since with this result the nation's ranking increases, meaning that more clubs can take part in the European championship the following year.

Furthermore, differently to what happens in other economic sectors, competitors are induced to develop and maintain collaborative agreements, not only in terms of organising better tournaments but also exploring new sources of income and exchanging ideas concerning best practice.

\section{Results}

Competition and co-operation in the sector of professional football must be kept within precise boundaries set by the sports' values and the rules of behaviour that should reflect these values.

It follows that, in the sector of professional football, the co-opetition model operates through tools that typically take the form of the rules governing the behaviour of the operators in the sector. These rules, basically, have the task of creating the correct balance between competition and co-operation.

From the viewpoint of co-operation, the rules put in place to protect competitive balance are extremely important. In general lines, these can be divided into rules that regulate the game and rules that oversee the administrative workings of the clubs.

Typical examples of rules belonging to the first category are the arrangements concerning the function of the referees.

This role became indispensible when the first football game regulations were introduced by the English Football Association in 1863. At that point, two officials were given the task of ensuring that the rules were respected, one nominated by each team playing. These umpires had no authority to stop the game, but the players could ask them to arbitrate over the interpretation of any action. Since the two officials almost never agreed, there was clearly the need for a third, neutral, official, who could be referred to (referee) over any dispute and was nominated in common agreement between the two clubs.

In 1891, the Football Association decided that the referees would become to sole judges of the correct proceedings of a match. They were given the discretionary power to punish faults in the game with free kicks and, for the first time, had the right to be on the pitch with the players. The two officials nominated by the teams become assistant referees and were placed along the touchlines.

While football had evolved enormously in terms of rules and tactics, the function of the referee and assistant referees has remained basically the same over the years, and their slowly acquired independence-economic and otherwise-has not made them immune from criticism and accusations of favouritism.

Economic theory explains the relationship between the referee and football teams through the agency model theory (Jensen and Meckling 1976). Football teams take on the role of principles, who give the agents (the referees) the task of ensuring that rules 
are respected. It follows that tools can be applied to prevent opportunistic behaviour on the part of the agents, in the form of incentives. These incentives can be used to align the objectives of the principles with those of the agent. This consideration is at the root of the decision taken by England in 2002, and subsequently by other European countries, to make the role of a referee a professional one.

Despite this drive to increase their professionalism, referees still are the subject of heavy criticism, where the theoretical matrix, excluding obvious clichés, can be traced back to the idea put forward by several economists (Akerlof 1980; Becker and Murphy 2000; Bernheim 1994) who believe that environmental conditions can influence the behaviour of individuals.

In order to limit the possibility that the external environment and/or certain psychological attitudes can influence, whether consciously or unconsciously, the way referees act, thereby allowing them to make systematic errors, proposals have been set forth from various sides concerning the use of technological tools to improve referee performance.

These proposals are based on the hypothesis that technology can reduce error, avoiding the situation whereby any individual match can be affected by incorrect decisions taken by the referee.

According to one part of the concept, using technological tools could risk increasing rather than reducing imbalance in matches.

Starting from the assumption that the errors made by referees are impartial, it can be shown (Groot 2008) that stronger rather than weaker teams would benefit most if these causal errors were not made, and this would load the competitive imbalance. In other words, a referee who makes an impartial, therefore causal, mistake will in fact help the weaker teams, resulting in a more balanced competition.

Other game-related rules that can influence the competitive balance concern the organisation of championships.

According to a study carried out by Cairns (1987), by reducing the number of teams challenging for a championship, this should increase uncertainty and ensure more uniformity in quality among the competing teams. Each additional match increases the proceeds made by the stronger teams more than proportionally compared to the increase in proceeds made by the weaker teams.

In other research (Hoehn and Szymanski 1999), it has been highlighted that, with the introduction of the Champions League, where participation is restricted to the best placed teams in every national league, there is the risk of reducing the competitive balance of national championships because of the fat profits made by the teams that compete as a club in the most important European competition.

Looking at the rules relating to the administrative workings of a club that could increase competitive balance, revenue sharing is probably the most important. This is, basically, a mechanism for redistributing among all clubs any kind of revenue obtained by the clubs individually or by the league as a whole.

In recent years, the topic of revenue sharing has been at the centre of a fiery debate concerning the methods of dealing with television rights from watching football in each country (Parlasca 2006). The confrontation is between, on the one side, those supporting a decentralised system where all sports clubs have individual contracts with media networks covering television-and-radio rights for home matches and, on the other, 
those supporting a centralised system in which each league in every country negotiates with the networks on behalf of all the championship matches, which involves splitting the revenue among the teams according to a specific distribution model.

In particular, those in favour of the latter system set out, as their principle argument backing this collective sale, the idea that centralised control over television rights and the distribution of revenue would ensure sufficient balance among the teams, since this balance is seen as the main means for keeping up the interest of football supporters.

The centralised model had been in place for several years in England. According to this model, $50 \%$ of the revenue is distributed equally, $25 \%$ consists in merit payment (which depends upon where a club finishes in the league table) and $25 \%$ in facility fees (paid according to how many times a club's matches are shown on UK television). In Italy, the model was only introduced recently and revenue is split according to the following allocation scheme:

- $40 \%$ equally among all top division (Serie A) teams.

- $30 \%$ based on results and, of this, $10 \%$ based on results achieved since 1946.

- The remaining $30 \%$ is split according to supporter pool size, with $25 \%$ based on the number of supporters for each team in the championship and $5 \%$ calculated on the basis of the population of the club's home town.

While the main European countries are in general moving towards a centralised model, the theoretic debate about the efficiency of revenue sharing in achieving the objective of increasing competitive balance is still basically open.

For a long time, economic literature (Quirk and El-Hodiri 1974; Fort and Quirk 1995; Vrooman 1995) on the subject has been dominated by what is known as the "invariance principle", according to which, revenue sharing has no impact on competitive balance.

According to Késenne (2007), the influence of revenue sharing on the competitive balance of the clubs changes depending on the model used to interpret it. In the hypothesis, for example, of an objective function that coincides with maximising the wins, revenue sharing always leads to greater competitive advantage, since poorer clubs can appropriate part of the revenue of richer teams and invest it to acquire several more talented players.

At the same time, Dobson and Goddard (2004) state that, where clubs act to maximise profit, the impact of revenue sharing will basically be zero (invariance principle) in a closed championship, with no promotions or relegations. In the hypothesis of an open championship, the impact of redistribution of revenue is not predictable and can even be negative.

This counter-intuitive conclusion is based on the idea presented by Szymanski and Késenne (2004), according to whom investment in talent is at the basis of wins, and these, in turn, are the premises for new revenue. When revenue is distributed, winning clubs can only gain part of the revenue they produced through their investments, and so they will tend to reduce their investment in new talented players. At the same time, losing clubs will gain part of the revenue that was due to the winning clubs, with the consequence that these weaker clubs will have little or no incentive to invest in new talent, since they can rely on part of the revenue which they were not responsible for producing.

It follows that the final outcome depends on the relationship between the weaker clubs' disincentive to buy new talented players and the richer clubs' disincentive to 
invest. If the former prevails on the latter, the overall result will be an increase in competitive imbalance. If the opposite is true, there will be in increase in competitive advantage. If the effects are balanced, the final result will be substantially zero, once more revealing the principle of invariance.

Feess and Stähler (2009) disagree with the above conclusions, stating that the model is based on the incomplete hypothesis that revenue increases in function of the relative quality of the clubs measured through the probability of winning. The authors propose, otherwise, a model where the football clubs' revenues depend, apart from on relative quality, also on absolute quality and the balance of competition. In this context, revenue sharing increases competitive balance if, with all other factors being equal, the clubs differ exclusively in terms of the impact of absolute quality on revenue. On the contrary, revenue sharing will have a negative impact on the balance of a competition if the hypothesis is that only relative quality plays a decisive role in incrementing revenue.

Among the rules that, over recent years, have had a major impact on the football system is the branch of studies covering the subject of access to national and international tournaments.

With the objective of growing the European football system from an organisational and management perspective and to ensure that tournaments are fair, including economically and financially, as from the season 2004-2005, only clubs in possession of a "UEFA Licence" can take part in European competitions.

To be issued a UEFA Licence, clubs must satisfy a number of requirements covering the sport and infrastructure and of a legal and economic-financial nature. The rules covering economic and financial matters are normally known as "financial fair play regulations". The main aim of these regulations is to provide greater assurance regarding the operational stability of clubs taking part in European competitions and to strengthen the process of promoting a management culture in the football world.

On the basis of the complex system of rules set out in the financial fair play regulations, clubs must show that they are viable as an ongoing concern, that there are no overdue debts towards their staff, the tax authorities or other football clubs and that they are able to match their costs with their operating income for the period.

The UEFA Club Financial Control Body was established to ensure that the financial fair play regulations are fully respected. This is a survey unit that is involved in the preliminary phase of the process and a judging unit that must take the final decisions.

In March 2012, sanctions were announced for potential non-fulfilment of the above, without, however, specifying what penalties would apply to which offences. The main sanctions that can be given include fines, loss of points, limiting the number of footballers who can play, disqualification from the current championship and exclusion from future championships.

\section{Discussion}

In this work, we followed a logical scheme that can be summarised below (Fig. 1):

We started from the definition of co-opetition and the theoretical framework of reference elaborated by Neale, according to whom, in the sports industry, it is necessary to distinguish between economic and sports competition. In a tournament, clubs compete between each other to gain the best possible result. In an economic competition, where 


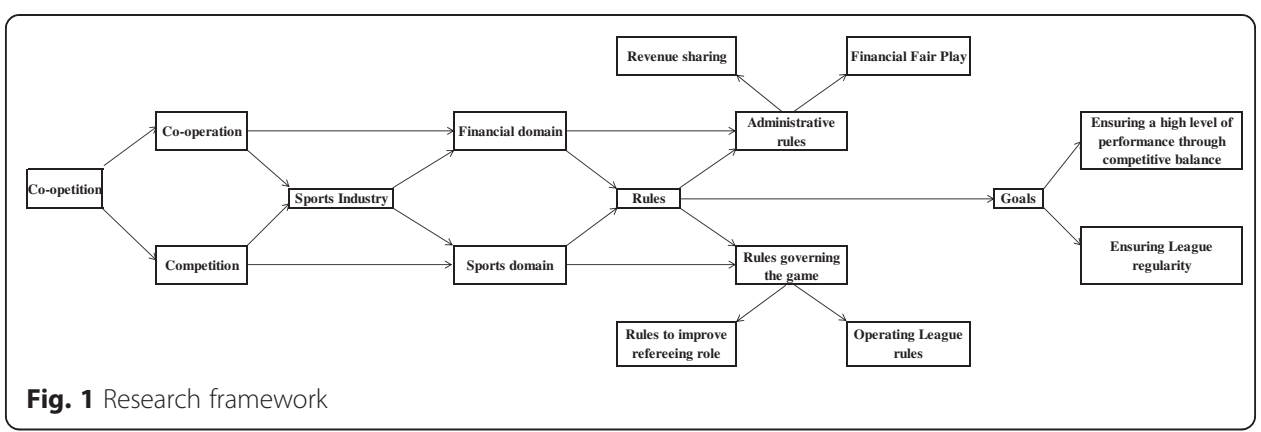

no team can individually satisfy the entire market demand, the football "product" realised by the clubs competes with any other product in the field of entertainment.

In this perspective, the rules are functional if two main objectives can be achieved. These are, on the one side, to ensure a high level of entertainment by maintaining a high competitive balance and, on the other, to ensure fair play in tournaments and so create a loyal following of clients for the product.

Within the paper, the rules are divided into two categories: administrative rules and rules of play.

While both fall into the category of administrative-type rules, regulations concerning the distribution of revenue do not have the same objective as those relating to "financial fair play". The former are in place to maintain competitive balance, the latter to ensure that tournaments can take place regularly and on a fair basis, avoiding the possibility that financial difficulties of individual clubs can reflect on the organisation of tournaments.

Among the regulations governing the workings of the game are the rules to improve refereeing and those overseeing the organisation of championships. From these regulations, it can be seen that, while the final aim is to ensure fair play in competition, there are repercussions on competitive balance. It has been shown that the introduction of technological tools can affect competitive balance indirectly, as does reducing the number of teams playing in a tournament, whether it is open or closed.

This consideration is seen to be important when looking at the true nature of the sports product, which is different from any other entertainment-type product.

It is well-known, in first place, that sports entertainment includes the fans or supporters, who will identify themselves with a particular team and would normally never contemplate turning their back on their favourite team because the results are not good or the ticket price does not match that of a rival team. The typical behaviour of an unhappy supporter is to desert the matches and, in the rather exceptional cases when they adopt a "second" team, go for teams in a different division or different sport. It is, therefore, possible to state that partisanship and habit are two of the most distinctive features in the relationship between supporters and teams and the origin of this support is often linked, although not always, to the supporters' place of birth or where they live.

In second place, it should be stressed that a sports event taking place in a stadium involves a wide variety of complementary products (Vrontis et al. 2014), such as food and drink, betting on the outcome, pre-game and mid-game entertainment, on top of the intangible product in the form of the atmosphere and the sense of sharing, known to draw in millions of spectators around the world. 
In third place, it is possible to state that sports entertainment is an experience involving-more or less-high suspense, which is, in turn, connected to the level of uncertainty in the outcome. While there is a conflicting body of empirical evidence concerning the impact of uncertainty on the number of spectators who watch a competition or even a single match (Neale 1964; Forrest and Simmons 2002; Szymanski and Késenne 2004; Parlasca 2006; Andreff and Raballand 2011), it is widely known that there is a close link between uncertainty and interest in a sports event.

Because of these features, sports entertainment is very different from any other form of entertainment, offering at one time the typical human experience of theatre and game.

Concerning game-related aspects, it has been observed (Caillois 1961) that, generally speaking, games can be classed according to which holds most sway among the four elements of competition, fortune, simulation and vertigo.

In this sense, football is a complex game, with, on the one hand, a very strong competitive element (the most talented team wins) and, on the other, a certain element of fortune that can, in some cases, overturn any prediction.

Since sports entertainment is an experiential resource defined by uncertainty, the optimal sports experience is based on the presumption of competitive balance. Indeed, in a sports context, the optimal experience takes place when there is the right blend between the level of challenge and the ability of those involved to handle the challenge.

The other aspect defining football entertainment is the social feeling of belonging, that is, that psychological and emotional state whereby football fans feel that they are part of a group acting for a common result. Although in high-business-intensity sports these feelings are blurred, the joy of holding a flag and the ensuing feelings of loyalty, solidarity and belonging are, without doubt, extremely effective as a glue binding club, team and supporters.

According to the perspective in question, football entertainment is a relational asset, where the role and intrinsic value of inter-personal relationships play a major part.

In the light of the above, it is possible to affirm that "football entertainment" is an extremely complex resource and cannot be placed within a single conceptual framework. The elements that best capture the peculiarities of this type of asset can be traced, on the one hand, to its experiential side and, on the other, to the importance, in terms of enjoyment, of the subjective aspect of relationships and the objective aspect of uncertainty in the outcome of the competition.

It follows that rules which ensure that both of the above elements can be retained are fertile ground for co-operation between clubs because it is in the interest of all the actors involved to make football entertainment more attractive, compared to competitive products.

On the other hand, Brandenburger and Nalebuff (1996) consider that sharing rules is one of the aspects on which a co-opetition relationship can be founded. We need to understand how far professional football clubs contribute towards defining the rules outlined above. It should be noted that, in the football context, rules belong to the category of metarules, since they are set by organisations outside the clubs.

However, it cannot be ignored that clubs are directly involved in the election process for organisations governing national federations, and these, in turn, constitute the active electorate for the governance bodies of international federations. 
In addition, it is clear that larger clubs are capable of influencing the process of defining the rules through lobbying initiatives and/or by nominating their own representatives to the most important governing bodies.

Differently from what has been stated in other works, it has been made clear in this study that professional football clubs can influence international federations in their process of elaborating rules to regulate the sector more effectively through lobbying than through the mediation of football leagues.

As can be seen in Fig. 2, the case presented in this paper completes the analysis of literature on co-opetition by highlighting:

1) The role of the specific aspects of the asset produced as the basic condition for creating systems of co-operation and competition

2) The role of lobbying in creating shared rules when the subject who is setting the rules does not belong to the network in which the rules are to be applied

Football is a hybrid system, in the sense that football clubs have an indirect role in setting the rules, being, directly or indirectly, part of those actively voting in and for national and international federal governance bodies.

\section{Conclusions}

In recent years, many scientific papers have been written about the determinants capable of influencing the demand of football entertainment. Among the most widely analysed variables are ticket price and supporter income (Andreff 1981; Bird 1982), costs for away games (Forrest et al. 2002), availability of audio-visual means or other media (Baimbridge et al. 1996), other sports events, club age, percentage of manual and nonmanual workers employed in a town (Dobson and Goddard 1995), the promotion and relegation system (Simmons 1996), the entertainment level (Andreff and Nys 1986) and in terms of comfortable and adequate sports infrastructure, home advantage (Forrest and Simmons 2002) and unemployment rates in a certain geographical area.

No analysis of the regulations governing the football system can ignore the determinants of the demand function of football entertainment, building on the study of the nature of this resource and the needs that are satisfied by enjoying this kind of entertainment.

In particular, it has been revealed that football entertainment can be defined as an experiential resource and its enjoyment is linked to the social dimension of relationships and the objective aspect of uncertainty about the outcome of the competition.

Although some scholars (Andreff and Raballand 2011) have cast doubt on the relationship between competitive balance and the reason why supporters attend a football

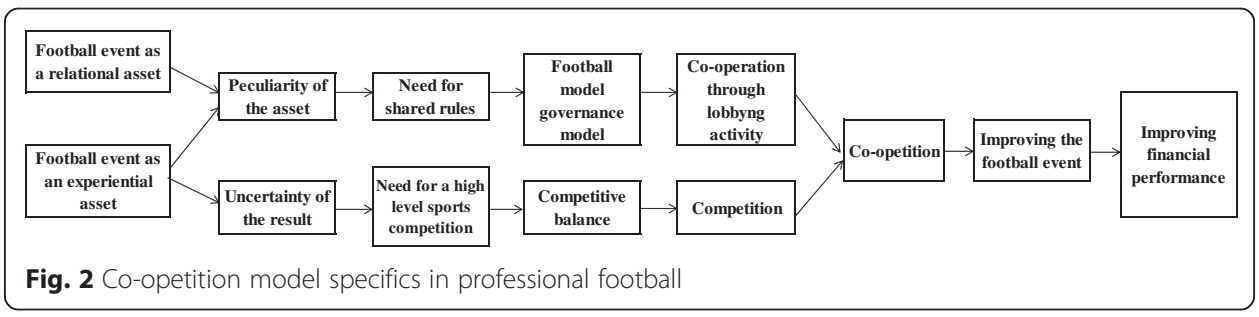


event, we believe that supporters are still strongly attracted by the intensity of the drama they are watching, which depends, in great measure, on the level of competition and the uncertainty of the results: all variables that can be summarised under the concept of "quality of the game".

It follows that an effective football system governance, in its entirety, cannot exclude the use of regulatory tools, covering the game of the administrative side of the clubs, whose purpose is precisely to increase balance in competitions.

The implication is to apply the co-opetition model to the management of football competitions. This model, as said previously, combines competition and co-operation with the function of creating and distributing value.

According to this approach, clubs have a central role in elaborating regulations, both in the name of a process to increase the value created and in consideration of the fact that, subsequently, they could gain a greater part of this value in virtue of a more intense competition.

In this paper, the objective is to identify the possible ways and means to apply a coopetition model, also highlighting the importance of lobbying activity carried out by professional football clubs.

Future research can be carried out to examine empirically the impact of regulations already in place on competitive balance and, also, to see whether it makes sense introducing to football regulations in other professional sports, which relate to technological tools for helping referees and maximum salary thresholds for athletes.

Competing interests

The authors declare that they have no competing interests.

\section{Authors' contributions}

Although this article is the result of a group effort of analysis and reflection, AL authored the "Discussion" section, RT the "Methods" and "Conclusions" sections, RL the "Background" section, and GR the "Results" section. All authors read and approved the final manuscript.

\section{Authors' information}

Alessandra Lardo is a Ph.D. student in Business Administration in the Department of Economics and Law at the University of Cassino and Southern Lazio (Italy). She is an Adjunct Professor of International Accounting at the University of Cassino and Southern Lazio. Her research interests cover the following topics: business management, knowledge management, intellectual capital and intellectual property rights, intellectual asset management, international accounting, evaluation of firms and social media. She is an author of articles and chapters of books regarding intellectual capital, evaluation of intangible assets and accounting. She serves as a reviewer of international and peer-reviewed academic journals. She is a winner of the "2015 EMERALD/EMRBI Business Research Award for Emerging Researchers-Highly Commended Paper".

Raffaele Trequattrini is a Full Professor of Business Administration in the Department of Economics and Law at the University of Cassino and Southern Lazio in Italy, where he was appointed vice-chancellor. He had his Ph.D. in Business Administration at the University of Urbino. He was an associate professor of Business Administration. His research interests cover the following topics: corporate governance, corporate disclosure, intellectual capital, accounting, knowledge economy, decision-making, crisis of firms, business network and management of intangible assets. He has published refereed articles across a wide range of topics. In fact, he is an author of articles and monographs regarding accounting, corporate governance, corporate disclosure, intellectual capital, business network and management of intangible assets. He serves as an editorial board member and reviewer of international peer-reviewed academic journals. He is a member of the Research of Interest Committee on "Intellectual Capital" and Fellow EMAB at the EuroMed Research Business Institute. $\mathrm{He}$ is a member of the Accademia Italiana di Economia Aziendale (AIDEA) and Società Italiana di Ragioneria e di Economia Aziendale (SIDREA). He is the Scientific Coordinator of the LInC Laboratory of Intellectual Capital. He is a winner of the "2015 EMERALD/EMRBI Business Research Award for Emerging Researchers—Highly Commended Paper". Rosa Lombardi is an Assistant Professor of Business Administration at Link Campus University in Rome (Italy). She is eligible as Associate Professor under the Italian National Qualification. She had her Ph.D. in Business Administration at the University of Cassino and Southern Lazio where she has been Adjunct Professor of International Accounting and Research Fellow in Business Administration. She serves in the Editorial Board and Guest/Associate Editor of many international peer-reviewed academic journals published by Palgrave MacMillan, Springer, Emerald, Inderscience Publishers. Her research interests cover the following topics: corporate governance, corporate disclosure, intellectual capital, measurement performance, international accounting, evaluation firm and business network. She has publications (books, articles, proceedings, etc.) regarding mainly corporate governance, corporate disclosure, intellectual capital, management control and business networks. She is the Chair of the Research of Interest Committee on "Intellectual Capital" and Fellow 
EMAB at the EuroMed Research Business Institute. She is a member of the European Accounting Association (EAA), Business System Laboratory, LInC Laboratory of Intellectual Capital and SIDREA Società Italiana di Ragioneria e di Economia Aziendale. She is a winner of the "2015 EMERALD/EMRBI Business Research Award for Emerging Researchers-Highly Commended Paper".

Giuseppe Russo is an Associate Professor of Business Management, Department of Economics and Law, University of Cassino and Southern Lazio (Italy). He is the Master Coordinator of $I^{\circ}$ level both in Social Enterprise Management and in Innovation and in Public Administration Management. He had his Ph.D. in Business Administration at the University of Cassino and Southern Lazio. He is an author of books and articles regarding business management, knowledge economy, intellectual capital, planning and control.

\section{Author details}

${ }^{1}$ Department of Economics and Law, University of Cassino and Southern Lazio, Loc. Folcara, 03043 Cassino, Italy.

2Department of Research, University of Rome "Link Campus", Via Nomentana, 335-00162 Rome, Italy.

Received: 10 November 2015 Accepted: 5 January 2016

Published online: 12 January 2016

\section{References}

Akerlof, G. A. (1980). A theory of social custom, of which unemployment may be one consequence. The Quarterly Journal of Economics, 94, 749-775.

Andreff, W. (1981). Le prix du spectacle sportif et le comportement du spectateur (Le Spectacle Sportif). Paris: Presses Universitaires de France.

Andreff, W., \& Nys, J. F. (1986). Economie du sport, que sais-je? (p. 2294). Paris: Presses Universitaires de France.

Andreff, W., \& Raballand, G. (2011). Is European football future to become a boring game? In W. Andreff (Ed.), Contemporary issues in sports economics. Participation and professional team sports. Cheltenham: Edward Elgar Publishing.

Baimbridge, M., Cameron, S., \& Dawson, P. (1996). Satellite television and the demand for football: a whole new ball game? Scottish Journal of Political Economy, 43(3), 317-333.

Bakshi, N., \& Kleindorfer, P. (2009). Co-opetition and investment for supply-chain resilience. Production and Operations Management, 18(6), 583-603.

Becker, M. A., \& Murphy, K. (2000). Social economics. Cambridge: Harvard University Press.

Bernheim, B. D. (1994). A theory of conformity. Journal of Political Economy, 102, 841-877.

Bird, P. J. W. N. (1982). The demand for league football. Applied Economics, 14(6), 637-649.

Bojar, W., \& Drelichowski, L. (2008). Analysis of tendencies in agribusiness networking co-opetition in Poland and in the partner countries. Journal of Central European Agriculture, 9(3), 445-456.

Brandenburger, A. M., \& Nalebuff, H. J. (1996). Co-opetition. New York: Doubleday.

Caillois, R. (1961). Man, plays and games. New York: Thames and Hudson.

Cairns, J. A. (1987). Evaluating changes in league structure: the reorganisation of the Scottish Football League. Applied Economics, 19(2), 259-275

Campanella, F., Della Peruta, M. R., \& Del Giudice, M. (2013). The role of sociocultural background on the characteristics and the financing of youth entrepreneurship. An exploratory study of university graduates in Italy. Journal of the Knowledge Economy, 4(3), 244-259.

Carayannis, E. G., \& Campbell, D. F. (2006). Knowledge creation, diffusion, and use in innovation networks and knowledge clusters: a comparative systems approach across the United States, Europe, and Asia. USA: Greenwood Publishing Group.

Chase, R. L. (1997). The knowledge-based organization: an international survey. Journal of Knowledge Management, 1(1), 38-49.

Cherington, P. T. (1976). Advertising as a business force: a compilation of experiences (reissueth ed.). Manchester: Ayer Co Pub.

Cherubini, S., \& Pattuglia, S. (2009). Co-opetition. Co-operazione e competizione nella comunicazione e nei media. Milano: Franco Angeli.

Dagnino, G. B., \& Padula, G. (2002). Co-opetition strategy — a new kind of interfirm dynamics for value creation.

Dagnino, G. B., \& Rocco, E. (Eds.). (2009). Co-opetition strategy: theory, experiments and cases. Rutgers: Routledge.

Del Giudice, M., Carayannis, E. G., \& Della Peruta, M. R. (2012). Culture and cooperative strategies: knowledge management perspectives. Cross-cultural knowledge management, 49-62. New York: Springer.

Del Giudice, M., \& Maggioni, V. (2014). Managerial practices and operative directions of knowledge management within inter-firm networks: a global view. Journal of Knowledge Management, 18(5), 841-846.

Dobson, S. M., \& Goddard, J. A. (1995). The demand for professional league football in England and Wales, 1925-1992. The Statistician, 44(2), 259-277.

Dobson, S., \& Goddard, J. (2004). Revenue divergence and competitive balance in a divisional sports league. Scottish Journal of Political Economy, 51(3), 359-376.

Eisenhardt, K. M. (1989). Building theories from case study research. Academy of Management Review, 14(4), 532-550.

Eriksson, P. E. (2008). Procurement effects on co-opetition in client contractor relationships. Journal of Construction Engineering and Management, 134(2), 103-111.

Feess, E., \& Stähler, F. (2009). Revenue sharing in professional sports leagues. Scottish Journal of Political Economy, 56(2), $255-265$.

Forrest, D., \& Simmons, R. (2002). Outcome uncertainty and attendance demand in sport: the case of English soccer. The Statistician, 51(2), 229-241.

Forrest, D., Simmons, R., \& Freehan, P. (2002). A spatial cross-sectional analysis of the elasticity of demand for soccer. Scottish Journal of Political Economy, 49(3), 336-356.

Fort, R., \& Quirk, J. (1995). Cross-subsidization, incentives, and outcomes in professional team sports leagues. Journal of Economic Literature, 33, 1265-1299.

Glaser, B. G., \& Strauss, L. (1967). The discovery of grounded theory. Chicago: Aldine. 
Gnywali, D., He, J., \& Madhavan, R. (2006). Impact of co-opetition on firm competitive behavior: an empirical examination. Journal of Management, 32(4), 507-530.

Groot, L. (2008). Economics, uncertainty and European football (Trends in competitive balance). Cheltenham: Edward Elgar Publishing.

Gueguen, G. (2009). Co-opetition and business ecosystems in the information technology sector: the example of intelligent mobile terminals. International Journal of Entrepreneurship and Small Business, 8(1), 135-153. doi:10.1504/IJESB.2009.024109.

Hoehn, T., \& Szymanski, S. (1999). The Americanization of European football. Economic Policy, 14(28), 203-240.

Huberman, M., \& Miles, M. B. (2002). The qualitative researcher's companion. Thousand Oaks: Sage.

Jensen, M. C., \& Meckling, W. H. (1976). Theory of the firm: managerial behavior, agency costs and ownership structure. Journal of financial economics, 3(4), 305-360.

Késenne, S. (2007). The economic theory of professional team sports. An analytical treatment. Cheltenham, UK: Edward Elgar Publishing.

Kylänen, M., \& Rusko, R. (2011). Unintentional co-opetition in the service industries: the case of Pyhä-Luosto tourism destination in the Finnish Lapland. European Management Journal, 29(3), 193-205.

Lombardi, R., Trequattrini, R., \& Battista, M. (2014a). Systematic errors in decision making processes: the case of the Italian Serie A football championship. International Journal of Applied Decision Sciences, 7(3), 239-254.

Lombardi, R., Manfredi, S., \& Nappo, F. (2014b). Third party ownership in the field of professional football: a critical perspective. Business Systems Review, 3(1), 32-47.

Lorgnier, N., \& Su, C. J. (2014). Considering co-opetition strategies in sport tourism networks: a look at the nonprofit nautical sports clubs on the northern coast of France. European Sport Management Quarterly, 14(1), 87-109.

Luo, Y. (2004). Co-opetition in international business (1st ed.). Frederiksberg: Copenhagen Business School.

Neale, W. (1964). The peculiar economics of professional sports. Quarterly Journal of Economics, 78(1), 1-14.

Palacios-Marqués, D., Soto-Acosta, P., \& Merigó, J. M. (2015). Analyzing the effects of technological, organizational and competition factors on Web knowledge exchange in SMEs. Telematics and Informatics, 32(1), 23-32.

Parlasca, S. (2006). Collective selling of broadcast rights in team sports. In W. Andreff \& S. Szymanski (Eds.), Handbook on the economics of sport (pp. 719-729). Cheltenham: Edward Elgar Publishing.

Quintana-García, C., \& Benavides-Velasco, C. A. (2004). Co-operation, competition, and innovative capability: a panel data of European dedicated biotechnology firms. Technovation, 24, 927-938. doi:10.1016/S0166-4972(03)00060-9.

Quirk, J., \& El-Hodiri, M. (1974). The economic theory of a professional sports league. In R. G. Noll (Ed.), Government and the sport business (pp. 33-80). Washington: Brookings Institution.

Robert, F., Marques, P., \& Le Roy, F. (2009). Co-opetition between SMEs: an empirical study of French professional football. International Journal of Entrepreneurship and Small Business, 8(1), 23-43.

Simmons, R. (1996). The demand for English league football: a club level analysis. Applied Economics, 28(2), 139-155.

Song, D. W. (2003). Port co-opetition in concept and practice. Maritime Policy and Management, 30(1), 29-44 doi:10.1080/0308883032000051612.

Soto-Acosta, P., Popa, S., \& Palacios-Marqués, D. (2015). E-business, organizational innovation and firm performance in manufacturing SMEs: an empirical study in Spain. Technological and Economic Development of Economy. doi:10.3846/20294913.2015.1074126.

Stein, H. D. (2010). Literature overview on the field of co-opetition. Verslas: Teorija ir Praktika, 3, 256-265.

Stewart, B., Nicholson, M., \& Dickson, G. (2005). The Australian Football League's recent progress: a study in cartel conduct and monopoly power. Sport Management Review, 8(2), 95-117.

Szymanski, S., \& Késenne, S. (2004). Competitive balance and gate revenue sharing in team sports. The Journal of Industrial Economics, 52(1), 165-177.

Trequattrini, R., Lombardi, R., \& Nappo, F. (2012). The evaluation of the economic value of long lasting professional football player performance rights. Wseas Transactions on Business and Economics, 9(4), 199-218.

Vernhet, A., Auge, B., \& Fernandez, A. S. (2011). Dynamics between the French Federation of Rugby (FFR) and the National Rugby League (NRL): competition, co-operation or co-opetition? Paper presented at the conference of the European Association of Sport Management. Madrid: Spain.

Vrontis, D., Thrassou, A., Kartakoullis, N. L., \& Kriemadis, T. (2014). Strategic marketing planning for football clubs: a value-based analysis. Journal for Global Business Advancement, 7(4), 355-374.

Vrooman, J. (1995). A general theory of professional sports leagues. Southern Economic Journal, 61(4), 971-990.

Yin, R. K. (2003). Case study research: design and methods. Thousand Oaks: Sage.

Zineldin, M. (2004). Co-opetition: the organisation of the future. Marketing Intelligence and Planning, 22(7), 780-790 doi:10.1108/02634500410568600

\section{Submit your manuscript to a SpringerOpen ${ }^{\circ}$ journal and benefit from:}

- Convenient online submission

- Rigorous peer review

- Immediate publication on acceptance

- Open access: articles freely available online

- High visibility within the field

- Retaining the copyright to your article

Submit your next manuscript at $>$ springeropen.com 